\title{
Disaster risk assessment at Roburnia Plantation, Mpumalanga, South Africa
}

\begin{tabular}{|c|c|}
\hline \multicolumn{2}{|c|}{$\begin{array}{l}\text { Authors: } \\
\text { Rudzani A. Makhado }{ }^{1,2} \\
\text { Amani T. Saidi }{ }^{3}\end{array}$} \\
\hline $\begin{array}{l}\text { Affiliations: } \\
{ }^{1} \text { Research and } \\
\text { Section, Limpc } \\
\text { South Africa }\end{array}$ & $\begin{array}{l}\text { Evaluation } \\
\text { po Legislature, }\end{array}$ \\
\hline $\begin{array}{l}{ }^{2} \text { Disaster Man } \\
\text { Education Cen } \\
\text { University of } \mathrm{t} \\
\text { South Africa }\end{array}$ & $\begin{array}{l}\text { ggement and } \\
\text { tre for Africa, } \\
\text { he Free State, }\end{array}$ \\
\hline $\begin{array}{l}{ }^{3} \text { South African } \\
\text { Observation N } \\
\text { National Rese } \\
\text { Foundation, S }\end{array}$ & $\begin{array}{l}\text { Environmental } \\
\text { etwork, } \\
\text { arch } \\
\text { uth Africa }\end{array}$ \\
\hline $\begin{array}{l}\text { Corresponden } \\
\text { Rudzani Makh }\end{array}$ & $\begin{array}{l}\text { ce to: } \\
\text { ado }\end{array}$ \\
\hline $\begin{array}{l}\text { Email: } \\
\text { makhado2002 }\end{array}$ & $@$ @ahoo.com \\
\hline $\begin{array}{l}\text { Postal addres } \\
\text { Private Bag X9 } \\
\text { Polokwane } 07 \\
\text { South Africa }\end{array}$ & $\begin{array}{l}\text { 309, } \\
\text { o0, }\end{array}$ \\
\hline $\begin{array}{l}\text { Dates: } \\
\text { Received: } 26 \text { C } \\
\text { Accepted: } 25 \\
\text { Published: } 15\end{array}$ & $\begin{array}{l}\text { ct. } 2012 \\
\text { Apr. } 2013 \\
\text { July } 2013\end{array}$ \\
\hline $\begin{array}{l}\text { Keywords: } \\
\text { Disaster; Risk } \\
\text { Risk Equation; } \\
\text { Plantation }\end{array}$ & $\begin{array}{l}\text { Assessment; } \\
\text { Fire; Roburnia }\end{array}$ \\
\hline $\begin{array}{l}\text { How to cite th } \\
\text { Makhado, R.A } \\
\text { A.T., 2013, 'Dis } \\
\text { assessment at } \\
\text { Plantation, Mr } \\
\text { South Africa', } \\
\text { of Disaster Ris } \\
\text { Art. \#64, } 6 \text { pag } \\
\text { http://dx.doi. } \\
\text { jamba.v5i1.64 }\end{array}$ & $\begin{array}{l}\text { is article: } \\
\text { \& Saidi, } \\
\text { aster risk } \\
\text { Roburnia } \\
\text { umalanga, } \\
\text { àmbá: Journal } \\
\text { Studies 5(1), } \\
\text { es. } \\
\text { rg/10.4102/ }\end{array}$ \\
\hline $\begin{array}{l}\text { Copyright: } \\
\text { (C) 2013. The A } \\
\text { Licensee: AOS } \\
\text { OpenJournals } \\
\text { is licensed unc } \\
\text { Creative Comr } \\
\text { Attribution Lic }\end{array}$ & $\begin{array}{l}\text { uthors. } \\
\text { S } \\
\text { This work } \\
\text { ler the } \\
\text { nons } \\
\text { ense. }\end{array}$ \\
\hline 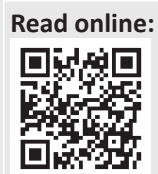 & $\begin{array}{l}\text { Scan this QR } \\
\text { code with your } \\
\text { smart phone or } \\
\text { mobile device } \\
\text { to read online. }\end{array}$ \\
\hline
\end{tabular}

This study reports about disaster risk assessment undertaken at Roburnia Plantation, Mpumalanga Province, South Africa. Both quantitative and qualitative approaches were followed to collect data. A total of eight experienced foresters and fire fighters were purposively sampled for interview at Roburnia Plantation. A questionnaire survey was also used to collect the data. Risk levels were quantified using the risks equations of Wisner et al. (2004) and the United Nations International Strategy for Disaster Reduction (UNISDR 2002). Data were analysed using descriptive and inferential statistics. Analysis of variance (ANOVA, single factor) was also applied. This study found that Roburnia Plantation is highly exposed to fire risks. The mean ( \pm s.d.) output from the Wisner risk equation shows that fire is the highest risk at $7.7 \pm 0.3$, followed by harsh weather conditions at $5.6 \pm 0.4$ and least by tree diseases, pests and pathogens at $2.3 \pm 0.2$. Similarly, the mean ( \pm s.d.) output from the UNISDR risk equation also shows that fire is the highest risk at $2.9 \pm 0.2$, followed by harsh weather conditions at $2.2 \pm 0.3$ and least by tree diseases, pests and pathogens at $1.3 \pm 0.2$. There was no significant deference in the risk analysis outputs $(p=0.13)$. This study also found that the number of fire incidents were low during summer, but increased during winter and spring. This variation is mainly due to a converse relationship with rainfall, because the availability of rain moistens the area as well as the fuel. When the area and fuel is moist, fire incidents are reduced, but they increase with a decrease in fuel moisture.

\section{Introduction}

Disasters are a complex mix of natural hazards and human actions, and their increasing occurrence hinders economic and human development across the world (Wisner et al. 2004). The United Nations International Strategy for Disaster Reduction (UNISDR 2005) revealed that disaster loss is on the rise, with grave consequences for the survival, dignity and livelihoods of individuals, particularly the poor in developing countries. It is generally believed that the increasing risk and vulnerability to disasters is a result of changing demographics, technological, political and socio-economic conditions, as well as unplanned urbanisation, development in high risk zones, environmental degradation, and climatic variability (UNISDR 2005; Wisner et al. 2004). The multiplicity of the causal factors of disasters shows the complexity associated with their prevention and management.

Commercial plantations in South Africa are frequently exposed to disaster risks such as fires, harsh climatic conditions, tree diseases, pests and pathogens. The occurrence of these disasters causes much damage to plantations. Records show that fires pose the highest risk to the sustainability of the forestry sector in South Africa. For instance, in a survey carried out by Forestry South Africa on behalf of the then Department of Forestry and Water Affairs in 2007/2008 found that of the 77150 ha of plantation that had been lost or destroyed, 70812 ha or $92 \%$ had been lost to or destroyed by fires (DWAF 2009). A combination of adverse weather conditions, diseases, insects and animals were responsible for the loss or destruction of the remaining 6338 ha or $8 \%$. It is similarly reported that about 994008 ha of plantation were damaged from 1980 to 2011 in South Africa and that the damage of 579728 ha or $58 \%$ of the total was caused by fires, whilst other causes accounted for the damage of the remaining 414280 ha or $42 \%$ of the total (Forestry \& Forest Product Industry 1980-2011).

Disasters have the potential to cause loss of livelihoods and services. Conducting disaster risk assessments is critical in order to reduce the possible effects of those disaster risks. As indicated by the UNISDR (2009), disaster risk assessments assist in determining the nature and extent of risk by analysing potential hazards and evaluating existing conditions of vulnerability that together could harm exposed people, property, services, livelihoods and the environment on which people depend. The most critical part of a disaster risk assessment is that data and information generated are useful in developing disaster risk prevention and control strategies. As also indicated by Jordaan (2006), scientific risk identification and analysis is crucial in order to provide accurate information for policy-making, risk prioritisation and the development of a reliable disaster risk index. 
The concept of risk analysis has evolved over time, and there is improvement in the recent risk analysis equations. However, a reliable and standardised risk equation is necessary in order to obtain similar results at international level. Wisner et al. (2004) indicated that:

the risk of disaster is a compound function of the natural hazard and number of people, characterised by their varying degrees of vulnerability to that specific hazard, who occupy the space and time of exposure to the hazard event. (p. 49)

There are basically two elements in the risk equation, namely hazard and vulnerability, as expressed in the following Wisner et al. (2004:49) risk equation:

$\mathrm{R}=\mathrm{H} \times \mathrm{V}$

[Eqn 1]

Where $\mathrm{R}=$ risk; $\mathrm{H}=$ hazard; $\mathrm{V}=$ vulnerability.

However, the Wisner et al. (2004) risk equation does not consider the capacity to deal with hazard. That gap is addressed in the UNISDR (2002) risk equation, which considers capacity in the equation. The UNISDR (2002:36) risk equation is expressed as follows:

$\mathrm{R}=\mathrm{H} \times \mathrm{V} / \mathrm{C}$

Where $\mathrm{R}=$ risk; $\mathrm{H}=$ hazard $; \mathrm{V}=$ vulnerability; $\mathrm{C}$ = capacity.

Various risks analysis equations have been developed around the world (e.g. Jordaan 2006; Kaji 2002; Morimiya 1992; Van Westen, Van Asch \& Soeters 2006), but they lack a standardised methodology. Jordaan (2006) indicated that the most commonly used formula in disaster risk assessments in South Africa is one that considers hazard, vulnerability and capacity in the risk equation. The risk equations presented in equations 1 and 2 above were developed by Wisner et al. (2004) and UNISDR (2002) respectively. This study applied both equations in order to assess the extent of fire disaster risk at Roburnia Plantation.

\section{Problem statement}

Fire is one of the major risks that negatively affect the sustainability of plantation forests in South Africa. Fire is one of the dominant disturbances in forest ecosystems (Flannigan, Stocks \& Wotton 2000), and its occurrence has the potential to destroy large numbers of hectares of plantation forests.

Fire occurs almost every year in the plantation forests in South Africa, and causes immense damage. However, the magnitude of fire risk and its impact has not been adequately addressed, particularly at a localised scale. The problem that this study sought to address was that of determining the extent of fire risk and its impacts at the Roburnia commercial forestry plantation in the Mpumalanga Province of South Africa.

\section{Methodology}

The study was conducted at the Roburnia Plantation, which is one of the Komatiland Forest Plantations, and is located at $26^{\circ} 40^{\prime} 04^{\prime \prime} \mathrm{S}$ and $30^{\circ} 44^{\prime} 18^{\prime \prime} \mathrm{E}$ near a small town called Amsterdam, Mpumalanga Province of South Africa. The types of tree species grown at Roburnia Plantation include pine, wattle and gum trees. The plantation is divided into two sections: the Roburnia and Blairmore sections. The total area in both sections is about 23000 ha. The area planted with commercial forests is about 16000 ha, whilst about 7000 ha are under indigenous vegetation cover. The reasons for choosing Roburnia forest plantation as the study area were twofold: firstly, Roburnia Plantation is located in the Mpumalanga Province - the province which has the highest number of commercial plantations in South Africa; and secondly, the same province annually experiences the highest number of fires that destroy plantations.

Both epistemological and scientific research designs were used in this study in order to assess the level of disaster risk. Quantitative data sets on factors that influence the occurrence of fire were collected. These include data on fire frequency, intensity, impact and the level of risk, and data on the number of hectares burnt by fire and economic losses. Qualitative data sets on perceptions of people towards the extent of fire were collected using questionnaire survey and interview methods. Secondary data sets were also collected from literature, including official documents and reports obtained from the management of the plantation.

A purposive sampling method was followed in order to identify individuals to be interviewed at Roburnia Plantation. This sampling technique was chosen in order to ensure that data and information were obtained from knowledgeable and experienced participants. The participants interviewed were foresters and fire fighters and had more than 10 years of experience in the forestry sector. A total of eight people were sampled for interviews, which included five forest managers and three fire fighters. They were interviewed in order to determine the extent and impact of disaster risks at the plantation.

Risk assessment score sheets were circulated via email, and also distribution to the offices for completion. A risk assessment matrix or score sheet was used to capture collected data. The matrix used was developed by the Ekurhuleni Metropolitan Municipality: Disaster Management Centre (2002) Risk Assessment Matrix, adapted by Maryna StrydomStorie. Hazard assessment was determined through scoring the frequency, intensity and overall rank of the identified risks (scale: from not likely to occur $=1$ to certain $=3$ ). The scores were added and then divided by 3 to give the hazard level. Vulnerability assessment was determined through scoring the impact of identified hazard on socio-economic and environmental issues (scale: from low $=1$ to high $=3$ ). The scores were added and then divided by 5 to give the vulnerability level. Capacity assessment was determined through scoring the capacity to respond to the hazard (scale: from poor $=1$ to good $=3$ ). The scores were added and then divided by 5 to give the capacity level. Secondary data were gathered through literature reviews in books, journals, reports and websites which are available and accessible in the public domain. Data on the number of hectares burnt, number of fires and fire extinguishing costs were downloaded from Disaster Management System (DMS) at the Roburnia Plantation. 
The datasets collected through the questionnaire and the risk assessment matrix were captured in Ms Excel 2007 and then analysed using descriptive and inferential statistical methods. The risk equations 1 and 2 presented earlier were then used to determine the levels of risk. Analysis of variance (ANOVA, single factor) was also applied in order to examine the relationship between the two equations.

\section{Results and discussion}

Before the risk could be determined, it was essential to first conduct a detailed hazard, vulnerability and capacity assessment as required in the risk assessment equations. The results of these assessments are presented below.

\section{Hazard assessment}

Major hazards identified at Roburnia Plantation include fires, harsh weather conditions, diseases, pests and pathogens (Table 1). If these hazards are not properly prevented and/ or managed, they have the potential to negatively affect the sustainability and productivity of the forest at the plantation. However, the degree to which the Roburnia Plantation is exposed to those hazards varies. As reflected in Table 1, the mean ( \pm s.d.) shows that fire is the single major hazard to forest sustainability at the plantation, at $3 \pm 0.0(41 \%)$, followed by harsh weather conditions at $2.7 \pm 0.4(36 \%)$ and lastly tree diseases, pests and pathogens at $1.7 \pm 0.3$ $(23 \%)$. The hazard assessment results suggest that there is high probability for fires to occur at Roburnia Plantation, and that when such fires occur they have potential to cause severe negative impacts. This implies that the management at Roburnia Plantation needs to develop plans and strategies to prevent the occurrence of these hazards. This supports the observation made by Wisner et al. (2004) that effective execution of disaster prevention plans and strategies could enhance resilience to hazards.

\section{Vulnerability assessment}

The Roburnia Plantation is highly vulnerable to the damaging effects of hazards such as fires, harsh weather conditions, tree diseases, pests and pathogens (Table 1). As reflected in Table 1, the mean ( \pm s.d.) shows that the Roburnia Plantation is highly susceptible to fire hazards at $2.6 \pm 0.5(43 \%)$, followed by harsh weather conditions at $2.1 \pm 0.5(35 \%)$ and lastly tree diseases, pests and pathogens at $1.4 \pm 0.2(23 \%)$. This means that if these hazards are not properly prevented, the plantation will be exposed to the hazards' potential negative impacts, which in turn would have detrimental effects on people's livelihoods. Other likely negative impacts include loss of life as a result of fires, destruction of infrastructure, loss of forest resources, and loss of employment.

The results obtained from the vulnerability assessment therefore suggest that management at Roburnia Plantation needs to address the factors that increase levels of vulnerability in order to reduce the exposure and susceptibility to fire hazard risks. As also indicated by Wisner et al. (2004), reducing vulnerability is a daunting task and all resources and efforts need to be mobilised and marshalled towards this goal.

\section{Capacity assessment}

As reflected in Table 1, the mean $( \pm$ s.d.) results obtained from the capacity assessment show that the management at Roburnia Plantation have the necessary capacity required to deal with risks such as fires at $2.7 \pm 0.4(38 \%)$ and harsh weather conditions at $2.6 \pm 0.4(37 \%)$. The management personnel at the plantation indicated that they annually conduct public awareness campaigns to sensitise their officials and members of the public on the dangers of fire. The idea is to inform them on how they can deal with fire incidents. They also indicated that they have a fire management plan which is reviewed annually in order to address gaps identified during the year.

The results show, however, that the management at Roburnia Plantation does not have sufficient capacity at $1.7 \pm 0.3(25 \%)$ to deal with other hazards such as tree diseases, pests and pathogens (Table 1). These results therefore suggest that the management at Roburnia Plantation also need to re-work their plans in order to address other risks besides fire.

\section{Application of Wisner and United Nations International Strategy for Disaster Reduction risk equations}

As stated earlier, the risk equations developed by Wisner et al. (2004) and UNISDR (2002) were used in the study in order to determine levels of risk at Roburnia Plantation.

\section{Application of the Wisner equation (Equation 1)}

Hazard and vulnerability variables are considered in the Wisner equation as the important variables in determining the level of risk (Wisner et al. 2004). The study used hazard and vulnerability variables following the Wisner equation in order to determine the extent of the risks at Roburnia Plantation. The mean ( \pm s.d.) analysis output shows that the level of risk varies. Fire is rated as the highest risk at $7.7 \pm 0.3$ $(49 \%)$, followed by harsh weather conditions at $5.6 \pm 0.4$ $(36 \%)$ and least by tree diseases, pests and pathogens at $2.3 \pm 0.2(15 \%)$ (Figure 1).

TABLE 1: Hazard, vulnerability and capacity assessment at Roburnia Plantation.

\begin{tabular}{|c|c|c|c|c|c|c|c|c|c|}
\hline \multirow[t]{2}{*}{ Disaster risk } & \multicolumn{3}{|c|}{ Hazard assessment } & \multicolumn{3}{|c|}{ Vulnerability assessment } & \multicolumn{3}{|c|}{ Capacity assessment } \\
\hline & mean & s.d. & $\%$ & mean & s.d. & $\%$ & mean & s.d. & $\%$ \\
\hline Fires & 3.0 & 0.0 & 41 & 2.6 & 0.5 & 43 & 2.7 & 0.4 & 38 \\
\hline Harsh weather conditions & 2.7 & 0.4 & 36 & 2.1 & 0.5 & 35 & 2.6 & 0.4 & 37 \\
\hline Trees, diseases, pests and pathogen & 1.7 & 0.3 & 23 & 1.4 & 0.2 & 23 & 1.7 & 0.3 & 25 \\
\hline
\end{tabular}

s.d., standard deviation.

$n=8$. 
Application of the United Nations International Strategy for Disaster Reduction equation (Equation 2)

The UNISDR (2002) equation, like the Wisner et al. (2004) equation, also considers hazard and vulnerability variables as important in risk analysis, but differs in the sense that it also includes capacity to respond to the identified hazards. The mean ( \pm s.d.) analysis output shows that the level of risk varies (Figure 2). Figure 2 shows that fire is rated as the highest risk at $2.9 \pm 0.2(45 \%)$, followed by harsh weather conditions at $2.2 \pm 0.3(34 \%)$ and least by tree diseases, pests and pathogens at $1.3 \pm 0.2(21 \%)$.

The study found that the two risk equations gave more or less the same results. The ANOVA single factor probability value between the two risk equations output was not significant ( $p=0.13)$. This means that the meaning and interpretation must be similar. This is against the findings of Nogueira, Luqi and Nada (2000), who indicated that the outcome of risk analysis would not necessarily be consistent because different experts could arrive at different conclusions from the same scenario. The most likely explanation why in this study the two models gave similar results was that the data sets used in both models were obtained from the same

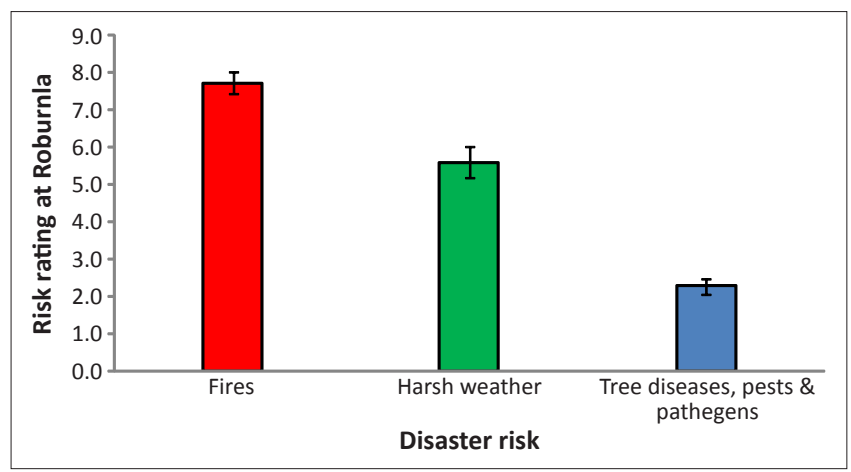

$n=8$.

FIGURE 1: Extent of risk at Roburnia Plantation using the Wisner equation.

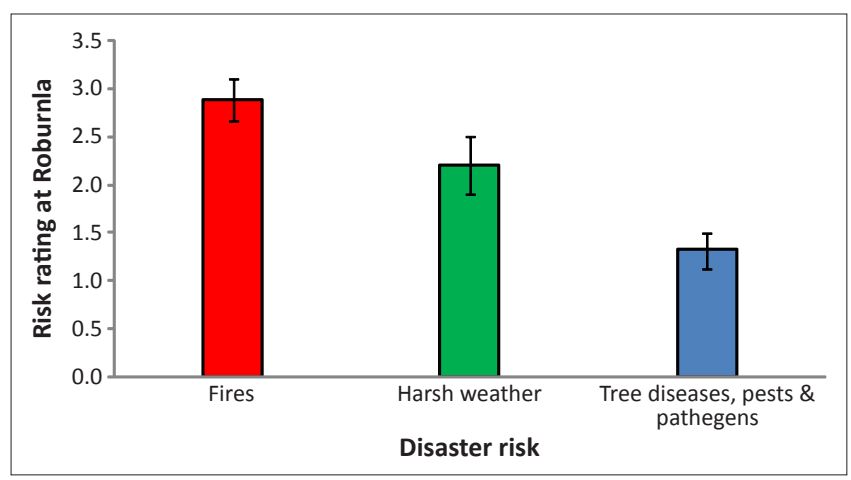

$n=8$.

FIGURE 2: Extent of risk at Roburnia Plantation using the United Nations International Strategy for Disaster Reduction equation. sources, namely experienced foresters and fire fighters. It follows therefore that possible errors or gaps in risk analysis can be reduced by interviewing experts, experienced and knowledgeable people.

\section{Impact of fires at Roburnia Plantation}

Fires occur annually, affecting many hectares of plantation forest at Roburnia Plantation. The major causes of fires at the plantation include arson, honey gathering, heavy machinery and lightning. However, arson appears to account for more than $70 \%$ of fires at Roburnia Plantation. Most of these fires occur at midday and in the evening. The results of this study concur with other studies which indicated that human activities are mainly responsible for major fires (e.g. Granger 1984; Leistikow, Martin \& Milano 2000; Working on Fire 2009).

This study has found that the tree species that are mostly affected by fires are gums, followed by pines. The gums are most affected by fires because they are highly flammable. They can burn even when the leaves are wet and green because the leaves of gum trees contain volatile substances which increase the intensity of fire.

\section{Number of fires and hectares burnt annually}

The number of fires and hectares burnt in South African commercial forest plantations varies annually, but they are on the rise (DWAF 2008). This study found that the number of fires and hectares burnt at Roburnia Plantation varies annually. Such variation also had results in differences in annual fire extinguishing costs (Table 2). The most fire incidents, amounting to 218, were recorded during the year 2010. However, the mean ( \pm s.d.) number of fires that occurred between 2007 and 2011 was $165.40 \pm 56.19$ (Table 2). The cause of the high number of fire incidents in 2010 is not clearly known by the management at Roburnia Plantation, but from the findings of this study it can be deduced that it could have been a result of the low amount of rainfall received in 2010. The total recorded rainfall for 2010 was $689 \mathrm{~mm}$, which was far below the average of $908 \mathrm{~mm}$ calculated from 1975 to 2011. Low rainfall in that year could have created conditions suitable for more outbreaks of fires.

Between 2007 and 2011, the largest area of forest destroyed by fire at Roburnia Plantation was 309.57 ha, which occurred in 2008. The mean ( \pm s.d.) number of hectares burnt between 2007 and 2011 were $126.45 \pm 110.81$ (Table 2).

The highest cost incurred for extinguishing fires was R725 969.92 and this was incurred in the year 2010. The mean ( \pm s.d.) amount incurred for extinguishing fires at Roburnia Plantation between 2007 and 2011 was R471 $903.01 \pm$ R256 330.32 (Table 2). The data presented in

TABLE 2: Impact of fires at Roburnia Plantation between 2007 and 2011.

\begin{tabular}{lccccccccc}
\hline Impact of fires & $\mathbf{2 0 0 7}$ & $\mathbf{2 0 0 8}$ & $\mathbf{2 0 0 9}$ & $\mathbf{2 0 1 0}$ & $\mathbf{2 0 1 1}$ & Min & Max & Average & s.d. \\
\hline Number of fires & 94 & 200 & 116 & 218 & 199 & 94 & 218 & 165.40 & 56.19 \\
Hectares burnt & 25.98 & 309.57 & 91.97 & 62.72 & 141.99 & 25.98 & 309.57 & 126.45 & 110.81 \\
Extinguishing costs (Rands) & 587143.84 & 93710.15 & 331567.84 & 725969.92 & 621123.30 & 93710.15 & 725969.92 & 471903.01 & 256330.32 \\
\hline
\end{tabular}

s.d., standard deviation. 
Table 2 implies that management at Roburnia Plantation needs to effectively implement fire prevention plans and strategies in order to ensure that the number of fires, hectares burnt and costs incurred due to extinguishing fires are drastically reduced. This clearly demonstrates the need to conduct risk assessment so that effective risk prevention plans and strategies can be developed and implemented.

\section{Seasonal variation in the number of fires and hectares burnt}

Data acquired from the study shows that there were seasonal variations in the number of fires and hectares burnt in 2011 (Figure 3). The ANOVA single factor analysis confirms that the number of fires is strongly correlated to the number of hectares burnt $(p=0.66)$. This means that an increase in the number of fires also results in an increase in the number of hectares burnt, and conversely, that a decrease in the number of fires also results in a decrease in the number of hectares burnt. This study found that the number of fire incidents was low during the summer months, but increased during winter and spring (Figure 3). This variation is mainly due to a converse relationship with rainfall. The availability of rain moistens the area as well as the fuel. During summer, the number of fires and hectares burnt are low because of the high moisture content, but the number of fires and hectares burnt increases during winter due to its low moisture content. These conditions influence fire ignition and complete burn during winter and spring (Figure 3).

Although the number of fires and hectares burnt increases from March, the highest peak was recorded in September (Figure 3). The findings of this study concur with other studies conducted in southern Africa, which indicated that the highest peak of fires occurs in August/September (e.g. Scholes, Ward \& Justice 1996; Van Wilgen, Trollope \& Everson 1990). However, some odd high incidents of fires might also occur in summer and autumn (Forsyth \& Van Wilgen 2008), mainly caused by lightning.

\section{Conclusion}

The study proved that possible risks can be identified by conducting disaster risk assessments. It was found that Roburnia Plantation is highly exposed to fire risks. A record of high frequency of fire occurrence, high exposure and vulnerability to fires at Roburnia Plantation suggests that there are high probabilities that this trend will continue in the future. The study further confirmed that data and information generated through risk assessment are essential for developing effective disaster risk prevention and control strategies. The advantage of preventing risk is that it significantly reduces the cost associated with disaster response, recovery and development, particularly in the long term. The current challenge hindering effective risk prevention plans at Roburnia Plantation, and in most plantations in South Africa, is that most resources are allocated for fire fighting and control, whilst meagre resources are allocated for risk assessment and prevention. Such a challenge requires that

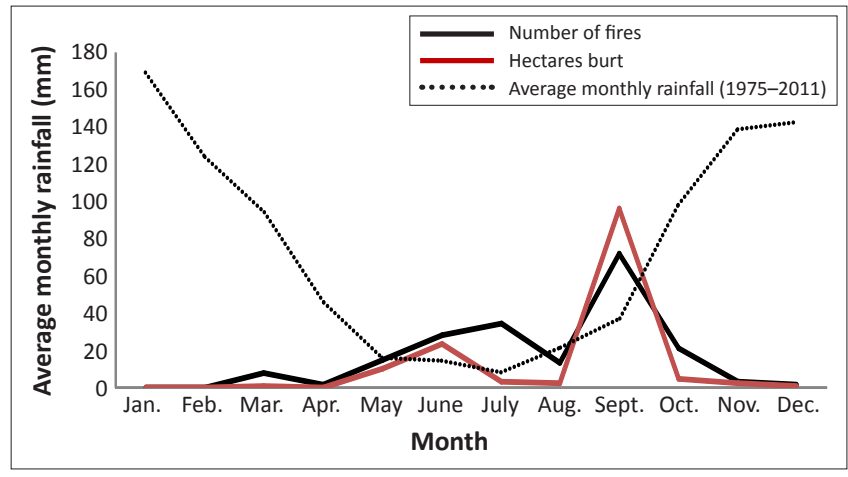

The data were compared with the average monthly rainfall (mm) measured from 1975 to 2011. FIGURE 3: Number of fires and hectares burnt at Roburnia Plantation in 2011.

plantation managers re-focus their strategies and deal with risk before the actual disaster event occurs.

An important finding of the study is that even if different risk equations are applied to analyse the risks, the outcome of such analysis provides similar results. Although this finding needs to be further tested, it nevertheless renders credence to the use of models and modelling techniques in risk assessment, particularly in situations where the sources of data used are reliable and trustworthy.

\section{Acknowledgements}

The authors acknowledge the financial support provided by the Department of Science and Technology (DST) and the National Disaster Management Centre (NDMC) towards the study from which this paper is an output. The management of Komatiland Forest are thanked for granting permission to conduct this study at Roburnia Plantation. Mr Roche Olivier (plantation manager), Mr Sizwe Gama (senior forester) and Ms Lindiwe Mthalane (forester) at Roburnia Plantation are acknowledged for assisting with all the data and information required during the study. We also acknowledge valuable comments provided by two anonymous reviewers.

\section{Competing interests}

The authors declare that they have no financial or personal relationship(s) that may have inappropriately influenced them in writing this article.

\section{Authors' contributions}

R.A.M. (Limpopo Legislature) was responsible for experimental and research design. He also collected the data, analysed them and wrote the article. A.T.S. (National Research Foundation) designed and supervised the study.

\section{References}

DWAF, 2008, 'Report on commercial timber resources and primary roundwood processing in South Africa', Department of Water Affairs and Forestry (DWAF), Pretoria.

DWAF, 2009, 'Report on commercial timber resources and primary roundwood processing in South Africa', Department of Water Affairs and Forestry (DWAF), Pretoria.

Flannigan, M.D., Stocks, B.J. \& Wotton, B.M., 2000, 'Climate change and forest fires', The science of the total environment 262, 221-229. http://dx.doi.org/10.1016/S00489697(00)00524-6 
Forestry \& Forest Product Industry, 1980-2011, 'Recently released data as contained in the 2009/10 and 2010/11 editions of DAFF's commercial timber resources and primary roundwood processing statistics', Forestry South Africa, South Africa, viewed primary roundwood processing statistics', Forestry
08 January 2013, from http://www.forestry.co.za

Forsyth, G.G. \& Van Wilgen, B.W., 2008, 'The recent fire history of the Table Mountain National Park and implications for fire management', Koedoe 50, 3-9. http://dx.doi. org/10.4102/koedoe.v50i1.134

Granger, J.E., 1984, 'Fire in forest', in P.V. Booysen \& N.M. Tainton (eds.), Ecological effects of fire in South African ecosystems, pp. 177-198, Springer-Verlag, New York. $\mathrm{http}: / / \mathrm{dx}$.doi.org/10.1007/978-3-642-69805-7_8

Jordaan, A.J., 2006, 'Disaster risk assessment: Thumb sucking or scientific risk quantification?', Disaster Management Institute of Southern Africa (DMISA), Hartenbosch.

Kaji, H., 2002, 'The successful experience in disaster risk management in Japan: Focus on earthquake disaster', Regional Workshop on Total Disaster Risk Management, 07-09 August 2002, Faculty of Policy Management, Keio University, Japan.

Leistikow, B.N., Martin, D.C. \& Milano, C.E., 2000, 'Fire injuries, disasters, and costs from cigarettes and cigarette lights: A global overview', Preventive Medicine 31, 91-99. http://dx.doi.org/10.1006/pmed.2000.0680, PMid:10938207

Morimiya, Y., 1992, 'What is risk?', Yobo-jiho, Japan Association of Fire and Marine Insurance, No. 168.

Nogueira, J., Luqi, V.B. \& Nada, N., 2000, 'A formal risk assessment model for software evolution', Proceedings of the 22nd International Conference on Software Engineering (ICSE 2000), Limerick, 04-11 June 2000, 2nd International Workshop on EconomicsDriven Software Engineering Research (EDSER-2), Limerick, Ireland.
Scholes, R.J., Ward, D.E. \& Justice, C.O., 1996, 'Emissions of trace gases and aerosol particles due to vegetation burning in southern hemisphere Africa', Journal of Geophysical Research 101, 23677-23682. http://dx.doi.org/10.1029/95JD02049

United Nations International Strategy for Disaster Reduction (UNISDR), 2009 'Terminology on disaster risk reduction', United Nations International Strategy for Disaster Reduction, Geneva, Switzerland.

United Nations International Strategy for Disaster Reduction (UNISDR), 2005, 'Hyogo framework for action 2005-2010: Building the resilience of nations and communities to disasters', Proceedings of the 2005 World Conference on Disaster Reduction, 18-22 January 2005, Kobe, Japan.

United Nations International Strategy for Disaster Reduction (UNISDR), 2002, 'Living with risk: A global review of disaster reduction initiatives', World Bank, Geneva.

Van Westen, C.J., Van Asch, T.W.J. \& Soeters, R., 2006, 'Landslide hazard and risk zonation - Why is it still so difficult?', Bulletin of Engineering Geology and the Environment 65, 167-184. http://dx.doi.org/10.1007/s10064-005-0023-0

Van Wilgen, B.W., Trollope, W.S.W. \& Everson, C.S., 1990, 'Fire management in southern Africa: Some examples of current objectives, practices and problems', in J.G. Goldammer (ed.), Fire in the tropical biota: Ecosystem process and global challenges, Ecological Studies 84, 179-215.

Wisner, B., Blaikie, P., Cannon, T. \& Davis, I., 2004, At risk: Natural hazards, people's vulnerability and disasters, 2 nd edn., Routledge, London.

Working on Fire, 2009, 'Integrated fire management: Fire awareness', viewed 08 June 2009, from http://www.workingonfire.org/ifm introduction.php 